Dept. of Microbiology,

Fac. Vet. Med., Kafr ELSheikh University.

\title{
STUDIES ON MICROBIAL CAUSES OF DIARRHOEA IN CALVES
}

(With 9 Tables and 4 Figures)

By

A.A. MOAWAD; SALWA M. HELMY; THANAA M. ELSHAYEB and I.E. ELDESOKY

(Received at 10/12/2007)

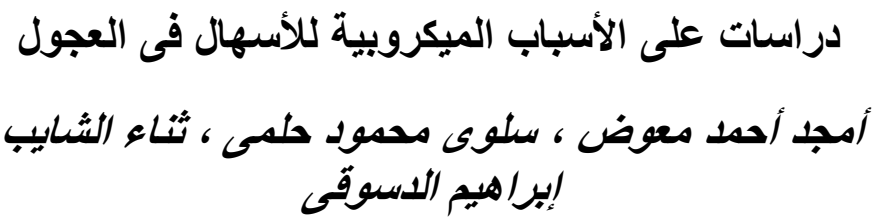

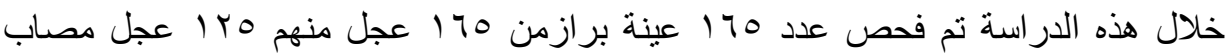

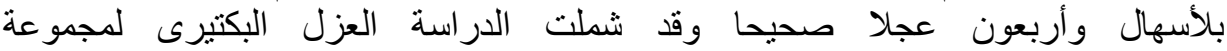

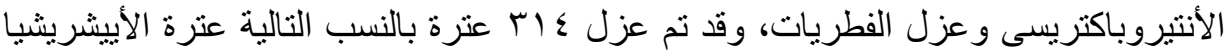

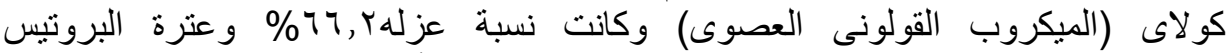

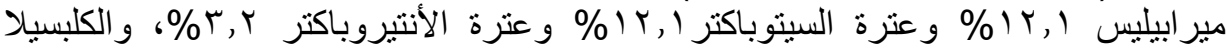

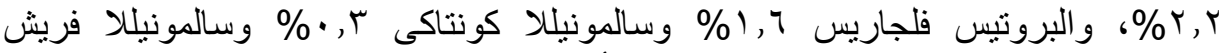

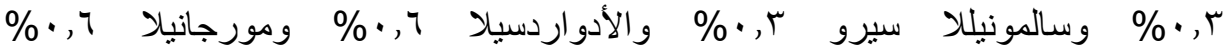

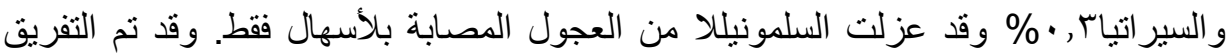

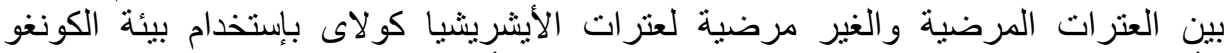

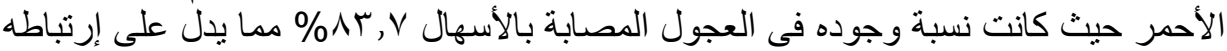

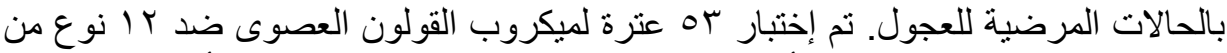

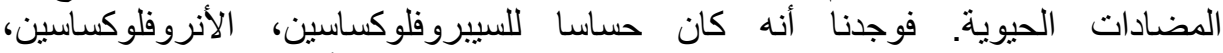

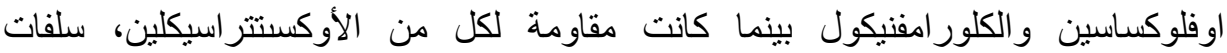

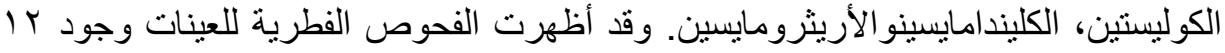

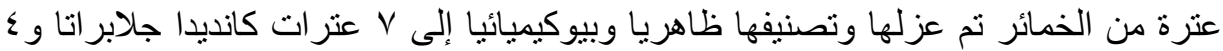

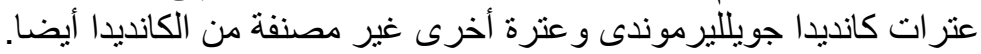

\section{SUMMARY}

In this study, a total of 165 calves (125 diarrhoeic and 40 healthy calves) were examined for bacteriological and mycological isolation to study the role of family Enterobacteriaceae and fungi in calf diarrhoea. A total of 314 bacterial isolates were recovered from examined calves and identified into E. coli (66.2\%), P. mirabilis (12.1\%), Citrobacter spp. 
(12.1\%), Enterobacter spp. (3.2\%), Klebsiella spp. (2.2\%), P. vulgaris (1.6\%), Salmonella spp. (0.9\%), Edwardsiella spp. (0.6\%), Morganella spp. (0.6\%) and Serratia spp. (0.3\%). Salmonella spp. had been recovered only from diarrhoeic calves. The recovered isolates were $S$. kentucky, S. ferruch and S. cerro ( $0.3 \%$ of each). Congo red binding activity of $E$. coli may be considered as an easy diagnostic tool for rough differentiation between pathogenic and non pathogenic strains. A total of 12 yeast isolates were recovered from examined calves and identified into Candida glabrata (58.3\%), Candida guillermondii $(33.3 \%)$ and other Candida spp. (8.33\%). In vitro sensitivity of E. coli to various antimicrobial agents revealed their sensitivity to ciprofloacin, enrofloaxin, ofloxacin and chloramphenicol, while they were resistant to oxytetracycline, colistine, clindamycine and erythromycine, on the other side, Salmonella spp. were varied in their sensitivity to different antimicrobial agents.

Key words:Diarrhoea, calves, Enterobacteriaceae, fungi, antimicrobial agents.

\section{INTRODUCTION}

Recently, neonatal calf diarrhoea remains one of the most important cause of calf mortality and is one of the major problems facing livestock production not only in Egypt but all over the world.

Each year thousands of neonatal calves are suffering from diarrhoea, resulting in economic losses these losses not only by increasing calf fatality but also by decrease in the calf's ability to gain weight, treatment cost, time spent on care as well as subsequent chronic ill thrift and poor growth (Bazeley, 2003).

It has been estimated that neonatal calf diarrhoea accounts for approximately $75 \%$ of the mortality of dairy calves under 3 weeks of age (Radostits et al., 1994).

Diarrhoea is a well known clinical sign in neonatal animals. Its etiology is complex involving managemental, environmental, nutritional, physiological variation and various infectious agents as bacterial, viral and protozoa (Marcio et al., 2000).

Family Enterobacteriaceae constitutes a great hazard to enteritis in newly born calves. E. coli and Salmonella take the major importance as a cause of diarrhoea (Ashraf, 1996).

The fungi, particularly yeasts and moulds are always neglected although they are well known to cause diseases of all animal species 
predisposing by their insensitivity to antibacterial antibiotics, so they usually flourish following prolonged antibiotic therapy.

So the aim of present work was planed as an attempt to study this problem from the following points of view:

1. To study the role of members of Enterobacteriaceae in calf diarrhoea.

2. Serological identification of the most predominant isolates to focus the most important serotypes involved in this condition.

3. Trails for isolation and identification of the possible fungal causative agents.

4. Finding the most effective antimicrobial agents to be used for treatment.

\section{MATERIALS and METHODS}

\section{1- Materials:}

\subsection{Calves:}

As shown in Table (1) a total of 165 calves were subjected to this investigation, out of which 94 cow-calves and 31 buffalo-calves were suffering from diarrhoea with variable degree.

The rest, 25 cow-calves and 15 buffalo-calves were apparently healthy normal calves from the same farms and were used as controls. All the investigated calves were 1-60 days old. Faecal samples were separately collected from examined calves using sterile disposable plastic gloves, which were inverted after sampling and information about date of sampling, number and age of the calf were written on each glove. Samples were collected from calves before any trial of treatment had been initiated. Faecal materials were transported to the laboratory in a cold chamber container to be cultured on the same day of sampling.

Table 1: Number, breeds and state of examined calves in different farms at Kafr El-Sheikh Governorate.

\begin{tabular}{|c|c|c|c|c|}
\hline \multirow{2}{*}{ Farms } & \multirow{2}{*}{ Species } & \multicolumn{2}{|c|}{ No. of examined calves } & \multirow{2}{*}{ Total } \\
\cline { 3 - 4 } & & Diarrhoeic & Apparently healthy & \\
\hline Sakha & Friesian & 44 & 13 & 57 \\
Karada & Friesian & 50 & 12 & 62 \\
Mehallet Mousa & Buffalo & 17 & 8 & 25 \\
El-Nataf & Buffalo & 14 & 7 & 21 \\
\hline \multicolumn{2}{|c|}{ Total } & 125 & 40 & 165 \\
\hline
\end{tabular}




\subsection{Bacteriological media:}

\subsubsection{Liquid media:}

- Nutrient broth (Oxoid)

- Tryptic Soya broth (Biolife)

- Rappaport Vassiliadis (Oxoid)

- Selenite F broth (Oxoid).

\subsubsection{Semisolid media (soft agar):}

Semisolid nutrient agar (Cruickshank et al., 1975).

\subsubsection{Solid media:}

- Nutrient agar (Oxoid).

- Mac Conkey's agar (Lab M).

- Eosine Methylene Blue agar (EMB) (Oxoid)

- Xylose Lysine Desoxycholate agar (XLD) (Oxoid)

- Salmonella-Shigella Agar (S.S) (Oxoid).

- Brilliant Green agar (B.G) (Oxoid)

- Blood agar media (Cruickshank et al., 1975) Blood agar base to which $5 \%$ defibrinated sheep's blood was added.

- Congo red medium (Berkhoff and Vinal, 1986).

- The medium consists of trypticase soya agar (Oxoid) supplemented by $0.03 \%$ Congo red dye (Sigma) and $0.15 \%$ bile salts (Sigma).

- Mueller Hinton media (Oxoid): for antibiotic sensitivity test

\subsubsection{Media used for biochemical identification of the isolates:}

All media used were prepared according to Cruickshank et al. (1975).

- Peptone water 2\% (Oxoid):

- Glucose Phosphate broth:

- Simmon's citrate agar (Oxoid):

- Christensen's urea agar base (Oxoid):

- Sugar fermentation media (Oxoid):

- Triple Sugar Iron Agar (TSI) (Oxoid):

- Lysine Iron Agar (LIA) (Sifin):

Table 2: Interpretation of reaction on TSI medium.

\begin{tabular}{|c|c|c|c|c|}
\hline \multicolumn{4}{|c|}{ Reaction } & \multirow{2}{*}{ Possible Organisms } \\
\hline Slant & Butt & Gas & $\mathrm{H}_{2} \mathrm{~S}$ & \\
\hline A & A & + & - & Escherichia and Klebsiella spp. \\
\hline K & A & + & + & Salmonella spp., Proteus spp. and Citrobacter spp. \\
\hline $\mathrm{K}$ & A & - & - & Enterobacter spp. and Shigella spp. \\
\hline A & A & + & + & Proteus vulgaris \\
\hline
\end{tabular}




\subsection{Media used for isolation of fungi:}

- Sabouraud's Dextrose Agar (SDA) (Oxoid)

- Sabouraud's dextrose broth (Oxoid)

\subsection{Media used for morphological identification of fungi:}

Rice Agar Medium (Refai M., 1987)

\subsection{Reagents and chemicals:}

- 3\% hydrogen peroxide solution for Catalase test.

- P. dimethyl amino benzaldhyde (Kovac's reagent) for Indole test.

- $1 \%$ tetramethyl-P-Phenylene diamine dihydrochloride, solution for Oxidase test.

- $0.04 \%$ methyl red solution for Methyl red test.

- Solution I of 5\% alpha naphthol in absolute ethanol. and solution II $40 \%$ potassium hydroxide for Voges Proskauer test.

- 40\% sterile urea solution (Oxoid, SR 20). For urease test.

- $1 \%$ Andrad's indicator.

- Potassium nitrate:for nitrate assimilation test.

- Sugars: glucose, lactose, sucrose, mannitol, galactose, mannitol, maltose, dulcitol and inositol.

\subsection{Diagnostic antisera:}

\subsubsection{Antisera used for serotyping of $E$. coli isolates.}

"O" sera 51 vials (polyvalent 8 vials and 43 monovalent vials) "SEIKEN" (product Code 312001, Japan).

- Polyvalent "1": $\mathrm{O}_{1}, \mathrm{O}_{26}, \mathrm{O}_{86 a}, \mathrm{O}_{111}, \mathrm{O}_{119} \mathrm{O}_{127 a}, \mathrm{O}_{128}$.

- Polyvalent "2": $\mathrm{O}_{44}, \mathrm{O}_{55}, \mathrm{O}_{125}, \mathrm{O}_{126}, \mathrm{O}_{146}, \mathrm{O}_{166}$

- Polyvalent "3": $\mathrm{O}_{18}, \mathrm{O}_{114}, \mathrm{O}_{142}, \mathrm{O}_{151}, \mathrm{O}_{157}, \mathrm{O}_{158}$

- Polyvalent "4": $\mathrm{O}_{6}, \mathrm{O}_{27}, \mathrm{O}_{78}, \mathrm{O}_{148}, \mathrm{O}_{159}, \mathrm{O}_{168}$.

- Polyvalent "5": $\mathrm{O}_{20}, \mathrm{O}_{25}, \mathrm{O}_{63}, \mathrm{O}_{153}, \mathrm{O}_{187}$

- Polyvalent "6": $\mathrm{O}_{8}, \mathrm{O}_{15}, \mathrm{O}_{115}, \mathrm{O}_{169}$

- Polyvalent "7": $\mathrm{O}_{28 \mathrm{ac}}, \mathrm{O}_{112 \mathrm{ac}}, \mathrm{O}_{124}, \mathrm{O}_{136}, \mathrm{O}_{144}$

- Polyvalent "8": $\mathrm{O}_{29}, \mathrm{O}_{143}, \mathrm{O}_{152}, \mathrm{O}_{164}$.

\subsubsection{Diagnostic Salmonella antisera:}

Diagnostic, polyvalent 1, II and III and monovalent Salmonella

$\mathrm{O}$ and $\mathrm{H}$ (phase 1 and phase 2) antisera were obtained from Denka Seiken, Japan.

\subsection{Antimicrobial sensitivity disks:}

- A total of 12 antimicrobial disks of Oxoid laboratory were used in the present investigation. they included, Chloramphenicol (C30 $\mu \mathrm{g})$,

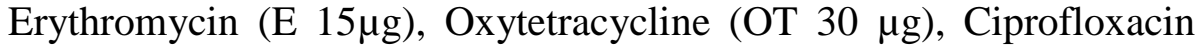
(CIP $5 \mu \mathrm{g}$ ), Ofloxacin (OFX $5 \mu \mathrm{g}$ ), Enrofloxacin (ENR $5 \mu \mathrm{g}$ ), Cefotaxime (CTX $30 \mu \mathrm{g}$ ), Clindamycine (DA $2 \mu \mathrm{g}$ ), Cephalexine (CL 
$30 \mu \mathrm{g}$ ), Ampicillin sulbactam (SAM $20 \mu \mathrm{g}$ ), Amoxycillin Clavulenic acid (AMC $30 \mu \mathrm{g}$ ), and Colistin sulphate (CT $25 \mu \mathrm{g}$ ).

\section{2- Methods:}

\subsection{Isolation of Enterobacteriaceae:}

Faecal samples were subjected for two methods of bacterial examination (Cruickshank et al., 1975).

\subsubsection{Direct plating method:}

A small quantity of faecal samples was plated onto the surface of MacConkey's agar plates. The inoculated plates were incubated aerobically at $37^{\circ} \mathrm{C}$ for $24-48$ hours.

\subsubsection{Selective enrichment method:}

About one gram of faeces was added to both $9 \mathrm{ml}$ of Rappaport Vassiliadis and Selenite F broths. After 18 hours of aerobic incubation at $37^{\circ} \mathrm{C}$, aloopful from cultivated broths was plated out on XLD, BG, S-S agar media, then incubated aerobically at $37^{\circ} \mathrm{C}$ for $24-72$ hours.

Pure colonies were picked up and preserved on slope agar for further morphological, biochemical and serological identification according Krieg and Holt (1984).

\subsection{Identification of the isolated bacteria.}

\subsubsection{Morphological and culture examination.}

Pure cultures were prepared from all suspected colonies, the shape, size, type of colonies either lactose or non lactose fermenting colonies onto MacConkey's agar or S-S agar and type of haemolysis on blood agar were recorded.

Films were prepared from the purified isolates, stained with Gram's stain and examined microscopically for detecting their staining reaction and morphological characters. Colonies showing the morphological characters of members of family Enterobacteriaceae were preserved on semisolid agar for further studies.

\subsubsection{Biochemical identification.}

The obtained bacterial isolates were examined for Catalase and Oxidase tests to be sure that they were belonged to family Enterobacteriaceae, then biochemical identification was achieved as described by Quinn et al. (2002). It included sugar fermentation (glucose, lactose, galactose, sucrose, xylose, mannitol, dulcitol, sorbitol and salicin), Indol production, Methyl red, Voges proskauer, Citrate utilization, Urea hydrolysis and $\mathrm{H}_{2} \mathrm{~S}$ Production.

\subsubsection{Detection of bacterial motility.}

Motility of the isolated bacteria was studied in soft agar $(0.5 \%$ agar) as described by Cruickshank et al. (1975). 


\subsubsection{Serological typing of isolated bacteria:-}

\section{a. Serological identification of $E$. coli:}

Isolates that were preliminary identified biochemically as E. coli were subjected to serological identification according to Ewing (1986).

Each isolate was first tested for its agglutinability of the diagnostic polyvalent "O" antisera, which are intended for use by slide agglutination technique. Once the pathogenic type has been indicated by the use of the polyvalent sera, further serogrouping was made with the appropriate"O" monovalent antisera.

\section{b. Serological identification of Salmonella:}

Isolates that were preliminary identified biochemically as Salmonella were subjected to serological identification according to Kauffmann-White scheme (Kauffmann, 1973) as follow:

2.2.5. In vitro differentiation between pathogenic and nonpathogenic $E$. coli:

Identified $E$. coli isolates were cultured on Congo red medium and incubated aerobically at $37^{\circ} \mathrm{C}$ for 24 hours and then left at room temperature for additional 2 days (not to exceed 4 days).

\subsection{Sensitivity of bacterial isolates to different chemotherapeutic agents:}

Bacterial isolates were tested for their susceptibility to 12 different antimicrobial disks according to test diffusion technique as described by Koneman et al. (1995).

\subsection{Isolation of fungi:}

Fecal samples were immersed in Sabouraud's dextrose broth with chloramphenicol and left for 18 hours before culturing.

A loopful from cultivated broth was streaked on SDA containing chloramphenicol at $37^{\circ} \mathrm{C}$ and $25^{\circ} \mathrm{C}$ for $4-6$ days. Isolates were kept on SDA slopes for further identification.

\subsubsection{Morphological identification of yeast.}

Yeast isolates were streaked on Rice agar plates and after 24-48 hours incubation at $30^{\circ} \mathrm{C}$, the plates were examined under the high power of ordinary microscope (Refai, 1987).

2.4.2. Biochemical identification of the isolated yeasts (Refai, 1987):

a. Sugar fermentation:

Glucose, galactose, sucrose, maltose and lactose sugar media were inoculated with the suspected isolates and incubated for 3-6 days at $37^{\circ} \mathrm{C}$. 


\section{b. Nitrate assimilation test:}

Nitrate assimilation medium was cooled to $45^{\circ} \mathrm{C}$ then poured into sterile Petri dishes containing $2 \mathrm{ml}$ saline suspension of the suspected isolates and finally left to dry at room temperature. Sterile filter discs previously soaked in 5\% peptone or potassium nitrate solution were put on the surface of the medium, then the plates were incubated for 2-4 days at $37^{\circ} \mathrm{C}$.

\section{c. Urease test:}

Christensen's urea agar slopes were inoculated with the suspected yeasts and then incubated at $25^{\circ} \mathrm{C}$ for 2-4 days.

\section{d. Germ tube test (Finegold and Baron, 1986):}

- A loopful of suspected yeasts inoculum was suspended in $0.5 \mathrm{ml}$ sterile bovine serum in test tube. The tubes were incubated for 3 hours at $37^{\circ} \mathrm{C}$, then one drop of yeasts serum mixture was examined microscopically for the presence of germ tube.

\section{RESULTS}

\section{Results of bacteriological examination of calves:}

Bacteriological examination of 165 faecal samples collected from diarrhoeic and apparently healthy calves revealed that a total of 314 bacterial isolates were recovered. The identification of such isolates revealed that 208 isolates of them belonged to $E$. coli with an incidence of $66.2 \%, 38$ isolates belonged to each P. mirabilis and Citrobacter spp. (12.1\% of each), 10 isolates belonged to Enterobacter spp. (3.2\%), 7 isolates belonged to Klebsiella spp. (2.2\%), 5 isolates belonged to P. vulgaris (1.6\%), two isolates belonged to each Morganella spp. and Edwardsiella spp. (0.6\% of each) and one isolate belonged to each $S$. kentucky, S. ferruch S. cerro and Serratia spp. (0.3\% of each).

\subsection{Recovered bacteria from diarrhoeic calves:}

As shown in Table (3) and Figure (1). A total of 259 bacterial isolates were identified. They include 166 isolates of E. coli $(64.1 \%), 35$ isolates of $P$. mirabilis (13.5\%), 31 isolates of Citrobacter spp. (12\%), 10 isolates of Enterobacter spp. (3.9\%), 6 isolates of Klebsiella spp. (2.3\%), 5 isolates P. vulgaris of 2 isolates of Edwardsiella spp. (0.8\%) and one isolate belonged to each S. kentucky, S. ferruch, S. cerro and Morganella spp. (0.4\% of each). 


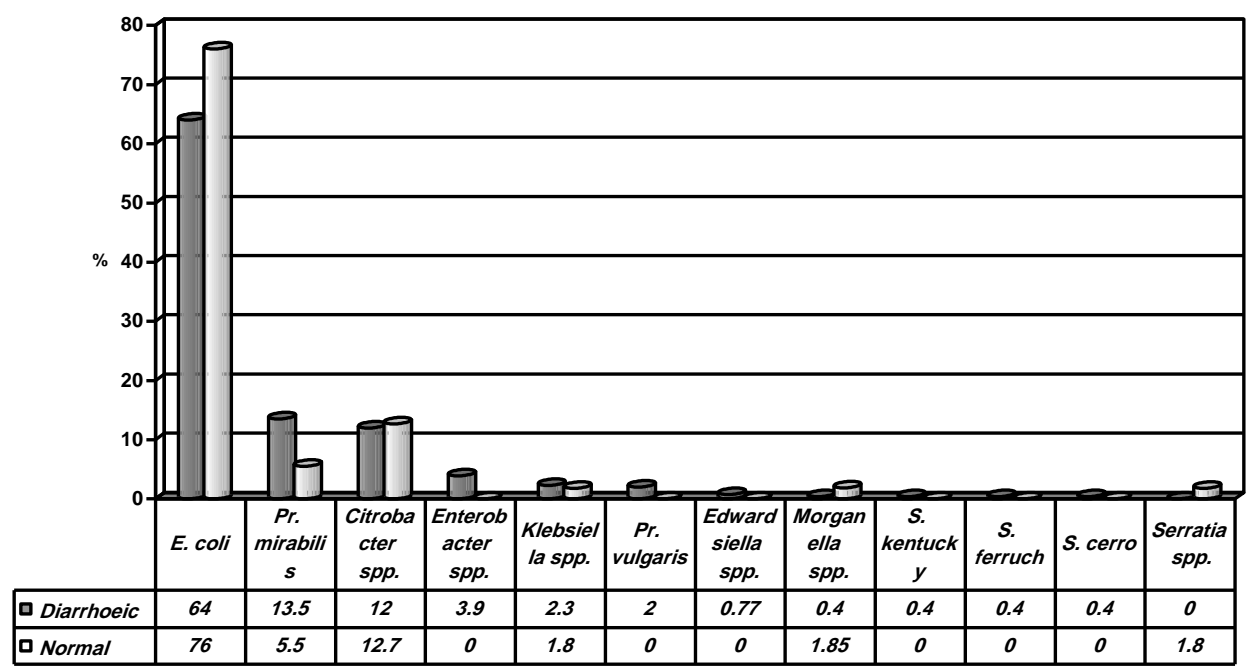

Fig. 1: incidence of recovered bacteria among the examined calves.

Table 3: Types of recovered bacteria from the examined calves.

\begin{tabular}{|c|c|c|c|c|c|c|}
\hline \multirow{2}{*}{ Recovered bacteria } & \multicolumn{2}{|c|}{ Diarrhoeic (125) } & \multicolumn{2}{|c|}{ Normal (40) } & \multicolumn{2}{|c|}{ Total (165) } \\
\hline & No. & $\%$ & No. & $\%$ & No. & $\%$ \\
\hline E. coli & 166 & 64.1 & 42 & 76.4 & 208 & 66.2 \\
\hline Pr. mirabilis & 35 & 13.5 & 3 & 5.5 & 38 & 12.1 \\
\hline Citrobacter spp. & 31 & 12 & 7 & 12.7 & 38 & 12.1 \\
\hline Enterobacter spp. & 10 & 3.9 & 0 & 0 & 10 & 3.2 \\
\hline Klebsiella spp. & 6 & 2.3 & 1 & 1.8 & 7 & 2.2 \\
\hline Pr. vulgaris & 5 & 2 & 0 & 0 & 5 & 1.6 \\
\hline Edwardsiella spp. & 2 & 0.77 & 0 & 0 & 2 & 0.6 \\
\hline Morganella spp. & 1 & 0.4 & 1 & 1.8 & 2 & 0.6 \\
\hline S. kentucky & 1 & 0.4 & 0 & 0 & 1 & 0.3 \\
\hline S. ferruch & 1 & 0.4 & 0 & 0 & 1 & 0.3 \\
\hline S. cerro & 1 & 0.4 & 0 & 0 & 1 & 0.3 \\
\hline Serratia spp. & 0 & 0 & 1 & 1.8 & 1 & 0.3 \\
\hline Total & 259 & 100 & 55 & 100 & 314 & 100 \\
\hline
\end{tabular}

\subsection{Recovered bacteria from apparently healthy calves:}

As shown in Table (4) a total of 55 bacterial isolates were recovered. They include 42 isolates of $E$. coli $(76.4 \%), 7$ isolates of Citrobacter spp. (12.7\%), 3 isolates of P. mirabilis (5.5\%) and one isolate belonged to each Klebsiella spp., Serratia spp. and Morganella spp. (1.8\% for each). 
Assiut Vet. Med. J. Vol. 54 No. 116 January 2008 


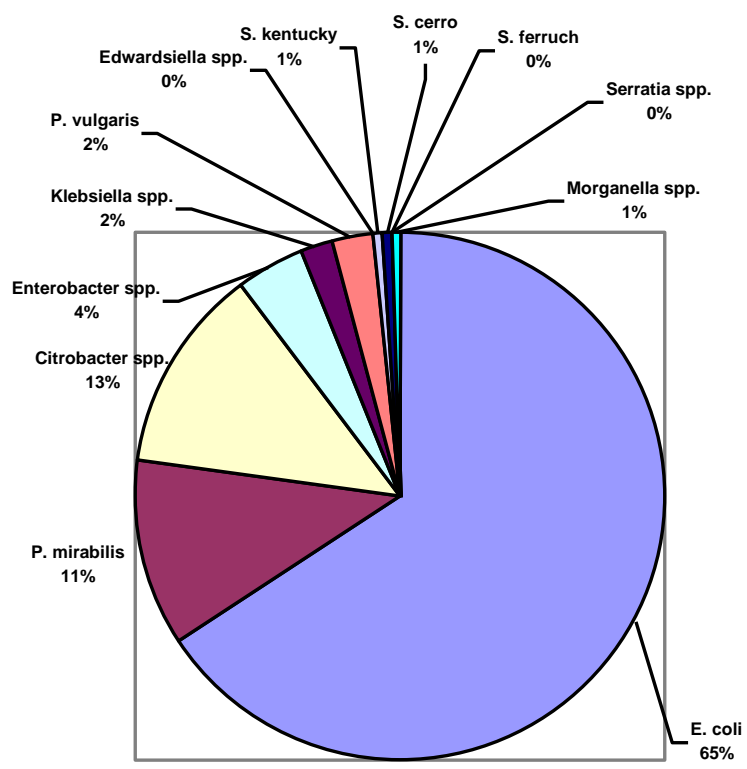

Fig. 2: Incidence of the recovered bacteria among examined cow calves.

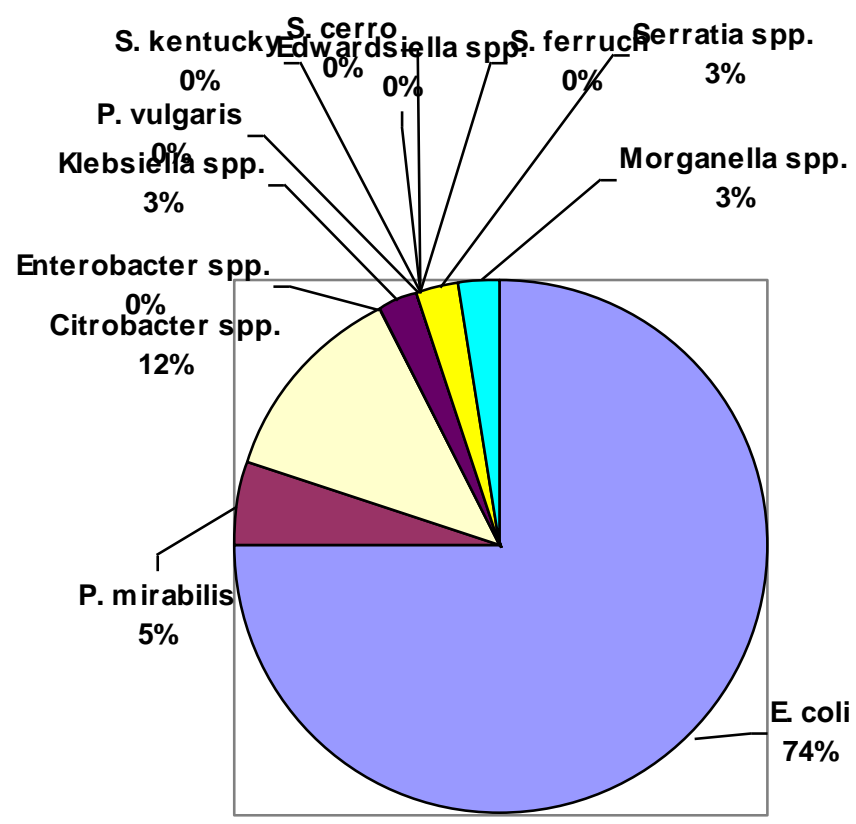

Fig. 3: Incidence of the recovered bacteria among examined apparently normal calves. 
Assiut Vet. Med. J. Vol. 54 No. 116 January 2008 
As shown in Table (5) a total of 32 cases from examined calves were contained more than one type of bacteria with a percentage of $19.3 \%$. They include 12 of $E$. coli with Citrobacter spp. (7.3\%), 8 of $E$. coli with P. mirabilis (4.8\%), 4 of E. coli with P. vulgaris (2.4\%), 3 of E. coli with Klebsiella spp. (1.8), 2 of E. coli with Morganella spp. $(1.2 \%)$ and the last three cases were E. coli with $S$. kentucky, E. coli with $S$. cerro and P. mirabilis with $S$. ferruch ( $0.6 \%$ of each).

\section{Results of serological identification of $E$. coli:}

The result of the serotyping of $10 \mathrm{E}$. coli isolates recovered from examined diarrhoeic calves revealed that $\mathrm{O}_{165}$ represent the most common serogroups ( 3 isolates) followed by $\mathrm{O}_{25}, \mathrm{O}_{115}, \mathrm{O}_{111}, \mathrm{O}_{167}$ and $\mathrm{O}_{1}$ (one isolate for each) and the last two serotypes were untypable.

\section{Results of serotyping of the recovered Salmonellae:}

A total of 3 isolates of Salmonellae were recovered from examined diarrhoeic calves and serologically typed as S.kentucky, S. ferruch and S. cerro (one for each) with an incidence of $0.3 \%$ (of each), as shown in Table (6).

Table 6: Serotyping of the recovered Salmonellae.

\begin{tabular}{|c|c|c|c|c|}
\hline Salmonella & No. of & Calf & \multicolumn{2}{|c|}{ Antigenic formula } \\
\hline Serovars & isolates & species & Group & \\
\hline S. kentucky & 1 & Cow & C & $\mathrm{O}_{8}-\mathrm{H}_{1 \mathrm{i}}-\mathrm{H}_{2} \mathrm{Z}_{4}$ \\
S. ferruch & 1 & Buffalo & C & $\mathrm{O}_{8}-\mathrm{H}_{12 h}-\mathrm{H}_{2} 1.5$ \\
S. cerro & 1 & Cow & & $\mathrm{O}_{6.14 .1}-\mathrm{H}_{1} \mathrm{Z}_{4} \cdot \mathrm{Z}_{23}-\mathrm{H}_{2}(1.5$ \\
\hline
\end{tabular}

\section{Congo red binding activity of the recovered $\boldsymbol{E}$. coli:}

As shown in Table (7) and Figure (4) a total of 208 isolates of $E$. coli (166 from diarrhoeic calves and 42 form apparently normal calves) were tested by their phenotype on Congo red medium.

Table 7: Results of in vitro differentiation between pathogenic and non pathogenic E. coli.

\begin{tabular}{|c|c|c|c|c|c|}
\hline \multirow{3}{*}{ Calf state } & No. of & \multicolumn{4}{|c|}{ Congo red reaction } \\
\cline { 3 - 6 } & examined & \multicolumn{3}{|c|}{$+\mathrm{ve}$} & \multicolumn{2}{|c|}{$-\mathrm{ve}$} \\
\cline { 3 - 6 } & E. coli & No. & $\%$ & No. & $\%$ \\
\hline Diarrhoeic & 166 & 139 & 83.7 & 27 & 16.3 \\
Normal & 42 & 13 & 31 & 29 & 69 \\
\hline Total & 208 & 152 & 73 & 56 & 27 \\
\hline
\end{tabular}

As shown in Table (7), 152 isolates (73\%) produced red colonies, 139 from diarrhoeic calves $(83.7 \%)$ and 13 from apparently normal 
calves $(31 \%)$ while 56 isolates $(26.9 \%)$ produced white colonies (27 from diarrhoeic calves $(16.3 \%)$ and 29 from apparently normal calves $(69 \%)$.

6. Antibiotic susceptibility of $E$. coli isolated from diarrhoeic calves:

As shown in Table (8) a total of 53 isolates of E. coli were tested for their sensitivity to 12 antimicrobial agents. Most of the tested isolates were highly sensitive to ciprofloxacin, enrofloxacin and ofloxacin, but they were sensitive to chloramphenicol, ampicillin and cefotaxime, on the other hand, the tested isolates were resistant to oxytetracycline, colistin sulphate, clindamycin, erythromycin and amoxycillin.

\section{Antibiotic susceptibility of Salmonella species isolated from} diarrhoeic calves:

As shown in Table (8), 3 isolates of Salmonella recovered from diarrhoeic calves were tested for their sensitivity to antimicrobial agents.

S. kentucky was highly sensitive to chloramphenicol, cefotaxime, amoxycillin and ampicillin, while it was completely resistant to ciprofloxacin, erythromycin, ofloxacin, clindamycine and oxytetracycline.

Table 8: Results of antibiogram of the isolated bacteria.

\begin{tabular}{|l|c|c|c|c|c|c|c|c|c|c|c|c|}
\hline \multirow{2}{*}{$\begin{array}{c}\text { Antimicrobial } \\
\text { agents }\end{array}$} & \multicolumn{3}{|c|}{ E. coli (53) } & \multicolumn{3}{c|}{ S. kentucky (1) } & \multicolumn{3}{c|}{ S. ferruch (1) } & \multicolumn{3}{|c|}{ S. cerro (1) } \\
\cline { 2 - 12 } & No & $\%$ & Result & No & $\%$ & Result & No & $\%$ & Result & No & $\%$ & Result \\
\hline Ciprofloxacin & 51 & 96.23 & $\mathrm{~S}$ & 1 & 0 & $\mathrm{R}$ & 1 & 100 & $\mathrm{~S}$ & 1 & 0 & $\mathrm{R}$ \\
Enrofloxacin & 47 & 88.68 & $\mathrm{~S}$ & 1 & 100 & $\mathrm{~S}$ & 1 & 100 & $\mathrm{~S}$ & 1 & 0 & $\mathrm{R}$ \\
Ampicillin & 29 & 54.72 & $\mathrm{~S}$ & 1 & 100 & $\mathrm{~S}$ & 1 & 0 & $\mathrm{R}$ & 1 & 100 & $\mathrm{~S}$ \\
Amoxycillin & 19 & 35.84 & $\mathrm{R}$ & 1 & 100 & $\mathrm{~S}$ & 1 & 0 & $\mathrm{R}$ & 1 & 100 & $\mathrm{~S}$ \\
Erythromycine & 21 & 39.62 & $\mathrm{R}$ & 1 & 0 & $\mathrm{R}$ & 1 & 0 & $\mathrm{R}$ & 1 & 0 & $\mathrm{R}$ \\
Chloramphenicol & 41 & 77.3 & $\mathrm{~S}$ & 1 & 100 & $\mathrm{~S}$ & 1 & 100 & $\mathrm{~S}$ & 1 & 100 & $\mathrm{~S}$ \\
Ofloxacin & 45 & 85 & $\mathrm{~S}$ & 1 & 0 & $\mathrm{R}$ & 1 & 100 & $\mathrm{~S}$ & 1 & 0 & $\mathrm{R}$ \\
Clindamycine & 8 & 15.1 & $\mathrm{R}$ & 1 & 0 & $\mathrm{R}$ & 1 & 0 & $\mathrm{R}$ & 1 & 0 & $\mathrm{R}$ \\
Oxytetracycline & 9 & 17 & $\mathrm{R}$ & 1 & 0 & $\mathrm{R}$ & 1 & 0 & $\mathrm{R}$ & 1 & 0 & $\mathrm{R}$ \\
Colistin & 16 & 30.2 & $\mathrm{R}$ & 1 & 0 & $\mathrm{R}$ & 1 & 0 & $\mathrm{R}$ & 1 & 100 & $\mathrm{~S}$ \\
Cephalexine & 13 & 24.5 & $\mathrm{R}$ & 1 & 100 & $\mathrm{~S}$ & 1 & 100 & $\mathrm{~S}$ & 1 & 100 & $\mathrm{~S}$ \\
Cefotaxime & 29 & 54.7 & $\mathrm{~S}$ & 1 & 100 & $\mathrm{~S}$ & 1 & 100 & $\mathrm{~S}$ & 1 & 100 & $\mathrm{~S}$ \\
\hline
\end{tabular}

S. ferruch was highly sensitive ciprofloxacin, cefotaxime and enrofloxacin, while it was resistant to erythromycin, oxytetracycline and clindamycine.

S. cerro was highly sensitive to chloramphenicol, cefotaxime and amoxycillin, but it was resistant to enrofloxacin, erythromycin, oxytetracycline and clindamycine. 
Collectively, all the tested Salmonellae varied in their sensitivity to ofloxacin, colistin, cephalexine, but they were completely resistant to erythromycin, oxytetracycline and clindamycine.

8. Results of fungal examination:

\subsection{Recovered fungi from diarrhoeic calves:}

As shown in Table (9) and Fig. (5) it is evident that 9 yeast isolates were obtained from 125 faecal samples of dirrhoeic calves (7.2\%). The identification of the isolates is demonstrated in Table (9) where 6 isolates were identified as Candida glabrata, 2 isolates as Candida guillermondii and one isolate of other Candida species.

\subsection{Recovered fungi from apparently healthy calves:}

Three yeast isolates were obtained from 40 faecal samples of apparently healthy calves (1.5\%) as indicated in Table (9) and Fig. (5) identified as C. glabrata (one isolate) and C. guillermondii (two isolates).

Table 9: Number of yeast isolates and their prevalence in faecal samples of examined calves.

\begin{tabular}{|c|c|c|c|c|c|c|}
\hline \multirow{2}{*}{$\begin{array}{c}\text { Recovered } \\
\text { Yeasts }\end{array}$} & \multicolumn{2}{|c|}{ Diarrhoeic } & \multicolumn{2}{c|}{ Apparently healthy } & \multicolumn{2}{c|}{ Total } \\
\cline { 2 - 7 } & No. & $\%$ & No. & $\%$ & No. & $\%$ \\
\hline C. glabrata & 6 & 66.6 & 1 & 33.3 & 7 & 58.3 \\
C. guillermondii & 2 & 22.2 & 2 & 66.6 & 4 & 33.3 \\
Other Candida spp. & 1 & 11.1 & 0 & 0 & 1 & 8.33 \\
\hline Total & 9 & 100 & 3 & 100 & 12 & 100 \\
\hline
\end{tabular}

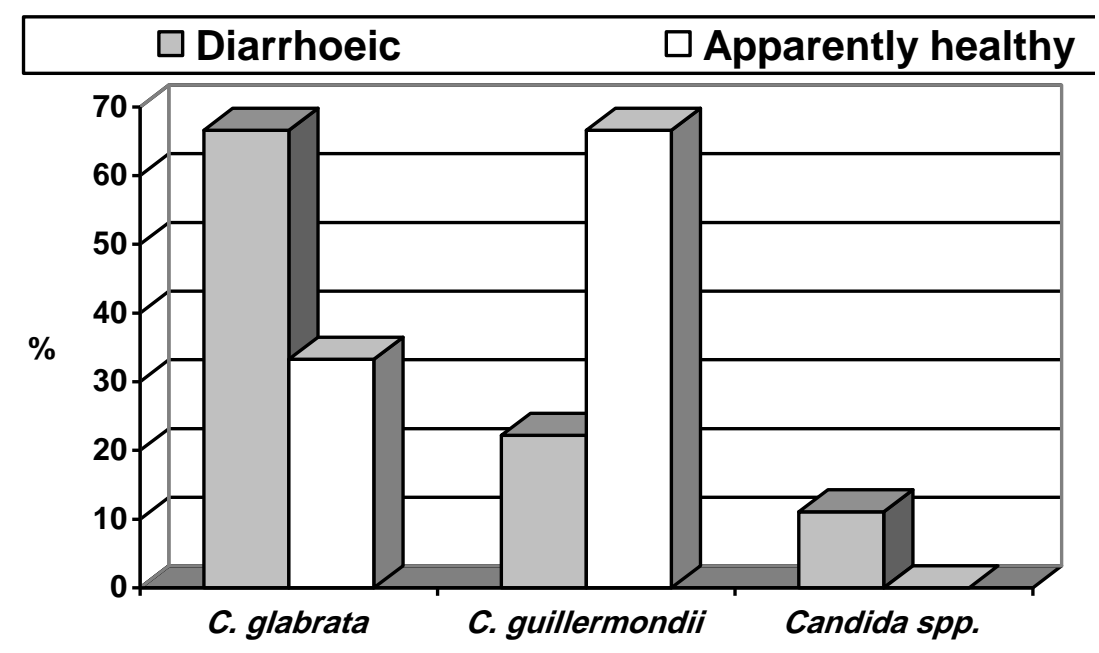

Fig. 4: incidence of yeast isolated from examined calves. 


\section{DISCUSSION}

During the last decade, a great attention was paid towards calf breeding projects to diminish the gap between the increased population and their demands from such animal proteins. Such projects were objected with many obstacles represented in a financial and general health condition that may lead to decrease in their productivity. Diarrhoea is one of main problems that face such projects. The disease remain largely unchecked because of its complex aetiology (Tzipori, 1981).

The recovered bacterial isolates were E. coli (208 isolates), $P$. mirabilis (38), Citrobacter spp. (38), Enterobacter spp. (10), Klebsiella spp. (7), P. vulgaris (5), Edwardsiella spp. (2), Morganella spp (2), Salmonella spp. (3) and Serratia spp. (1) with an incidence of $66.2 \%$, 12.1\%. $12.1 \%, 3.2 \%$. 2.25\%, $1.6 \%, 0.6 \%, 0.6 \% 0.9 \%$ and $0.3 \%$ respectively

The result in the present thesis showed that E. coli was the predominant spp. among members of family Enterobacteriaceae. This result coincides with that mentioned by Ashraf (1996).

In the present study, E. coli was isolated with an incidence of $64 \%$ and $76 \%$ from diarrhoeic and healthy calves respectively. These results agree with the result obtained by Navade et al. (2000) who recorded that $E$. coli was the primary cause of diarrhroea. The second, third, fourth and fifth authors reported that its incidence were 53\%, 66\%, $68.6 \%$ and $68 \%$, respectively. This high incidence of $E$. coli in the diarrhoeic calves let us to conclude that $E$. coli is the most common cause of diarrhoea, although various types of $E$. coli are normal inhabitants in the intestine.

Meanwhile, other researcher isolated E. coli from diarrhoeic calves with relatively low incidence as described by Tanios et al. (2000) who isolated $E$. coli with an incidence of $10.8 \%, 34 \%, 28 \%, 32.8 \%$, $14.5 \%, 37 \%, 33.3 \%, 33 \%, 32 \%$ and $34.9 \%$ in there order, on contrary higher incidence of E. coli was recorded by Oliveir et al. (1989) and Ashraf (1996). Their results were $74.45 \%, 95.4 \%$ and $79.7 \%$, respectively. These variation may be attributed to the pathogenicity of E. coli for calves which had been correlated with numerous extrinsic and intrinsic factors. These extrinsic factors include environmental condition, exposure to other infectious agent, improper feeding, unsanitary condition for drinking, bad hygienic surrounding and deprivation of colostrum one of the most important factors. Some 
viruses and bacteria beside the bad sanitary environmental condition assist the pathogenecity of E. coli, such facts was previously mentioned by Woode and Bridger (1975).

Serotyping of the recovered $E$. coli is not only useful procedure for epidemiological purpose, but also as a tool for delimiting different pathophysiological syndrome. The serological identification of the recovered $E$. coli were $\mathrm{O}_{111}, \mathrm{O}_{115}, \mathrm{O}_{165}, \mathrm{O}_{167}, \mathrm{O}_{167}, \mathrm{O}_{1}, \mathrm{O}_{25}$ and untypable strains. These results agree with Tanios et al. (2000) who isolated two isolates of E. coli belonged to $\mathrm{O}_{111}$ from diarrhoeic calves and Farid et al. (1976) who proved that $\mathrm{O}_{111}$ and $\mathrm{O}_{115}$ serotypes were present as a causative agents of diarrhoea in calves.

The obtained result also simulated with the result recorded by Sirvastava and Arya (1979) who isolated E. coli from calves suffering from gastroenteritis and typed them as $\mathrm{O}_{25}$. Similar results also described by Verma and Aldakha (1970) who stated that the most strains of E. coli that associated with diarrhoea in calves belonged to $\mathrm{O}_{1}$ and $\mathrm{O}_{115}$.

Through this study, a total of three Salmonella serotypes (two from diarrhoeic cow calves and one from diarrhoeic buffalo calves) were recovered with an incidence of $0.9 \%$ and identified serologically as $S$. ferruch, S. cerro and S. kentucky. Our result showed that Salmonella spp. were isolated totally with an incidence of $0.95 \%$ which differs from that obtained by Tanios (2000) who recovered Salmonella spp. with an incidence of $18.5 \%, 4.7 \%, 7.7 \%, 23.6 \%, 8.6 \%, 8.9 \%$ and $13.6 \%$, respectively from diarrhoeic calves. The obtained result were simulated with the result recorded by Abou Zid (1976) who isolated two strains of S. typhimurium from 150 diarrhoeic calves and Zrelli et al. (1990). Who detected S. typhimurium in diarrhoeic calves with an incidence of $1.8 \%$.

Serotyping of recovered Salmonella spp. revealed that $S$. ferruch was isolated from diarrhoeic buffalo calves with a percentage of $0.3 \%$.

The incidence of $\mathrm{S}$. ferruch recorded in the present study was nearly similar to that obtained by Abou Zid (1979). Single isolate of S. cerro was recovered in this study with a total percentage of $0.3 \%$ from diarrhoeic cow calves. These results are near to the results obtained by Labib (1998) who mentioned that the incidence of S. cerro recovered from calves with diarrhoea were $1.4 \%, 1.6 \%$ and $0.9 \%$ in their order.

Regarding to S. kentucky, it was isolated from diarrhoeic cow calves with an incidence of $0.4 \%$. According to the available literatures, it is the first record to be isolated from cow calves in Egypt.

From the above mentioned results, it could be concluded that all the recovered Salmonella serotypes were isolated from diarrhoeic calves, 
while, no Salmonella spp. were recovered from apparently normal calves. These results agree with that mentioned by Wani et al. (2003) that indicated their relation to the disease.

Wells et al. (2001) reported that Salmonella faecal shedding in milk cow was detected in $21 \%$ of dairies and $66 \%$ of cull dairy cow market and the most common serotypes of Salmonella shed from dairy cow were S. kentucky (8.05\%), S. cerro (13.3\%) and other type of Salmonellae, so in our study, isolation of these serotypes from diarrhoeic calves may be attributed to bad hygienic measures in the examined farms that lead to faecal contamination of udder of infected or carrier cow, subsequently infection of newly born calves during milk suckling.

Concerning the incidence of Proteus spp. as a causative bacterial agent of enteritis in calves in this study. The obtained finding revealed that it was present in the examined cases with an incidence of $13.7 \%$ out of them, P. mirabilis was the predominant spp. (12.1\%). P. mirabilis was recovered from diarrhoeic and healthy calves with an incidence of $13.5 \%$ and $5.5 \%$, respectively. $P$. vulgaris was isolated only from diarrhoeic calves with an incidence of $1.6 \%$. The obtained results are to certain extent near to the results obtained by Abd El-Galil et al. (1983) who isolated Proteus spp. from diseased buffalo calves with an incidence of 5\%, but our results disagree with the results recorded by Mona (1995a) who recovered P. mirabilis and P. vulgaris from calves with enteritis in a percentage of $1.33 \%$ and $13.32 \%$, respectively and Olivier et al. (1989) who stated that incidence of P. vulgaris recovered from diarrhoeic calves was $8.2 \%$. Also, the present results were lower than obtained by Al-Khayyat et al. (1977) who recovered Proteus spp. from diarrhoeic calves with an incidence of $25.33 \%$ and $18 \%$, respectively.

With regard to Citrobacter spp., they were recovered from diarrhoeic calves with a percentage of $12 \%$. This result agrees with that obtained by Vertanyan et al. (1990) who stated that Citrobacter spp. was the most prevalent bacteria among diarrhoeic calves after E. coli and Proteus spp. Also, the obtained results go hand in hand with those recorded by Marcio et al. (2000) who isolated Citrobacter spp. with an incidence of $12.5 \%$ from buffalo calves suffering from diarrhoea. The present results are higher than that obtained by Mona (1995a), Hussain and Saikia (2000) who recovered Citrobacter spp. with an incidence of $8 \%$ and $6.55 \%$, respectively. The obtained result showed that it was isolated with higher percentage form apparently healthy calves $(12.7 \%)$. This result agrees with that obtained by Corsalini (1969) who mentioned 
that Citrobacter spp. was the most frequent enterobacteria isolated from healthy calves.

Concerning Enterobacer spp. in the present investigation, it was recovered from diarrhoeic calves with an incidence of 3.9\%. These obtained results agree with that mentioned by Ashraf (1996), Hussain and Saikia (2000), who recovered Enterobacter spp. from diarrhoeic calves with an incidence of $3.6 \%$ and $2.45 \%$, respectively. The present results are different from that described by Marcio et al. (2000) who recorded high recovery rate of Enterobacter spp. with an incidence of $62.5 \%$ and $30.1 \%$ from diarrhoeic and apparently healthy calves respectively.

Regarding to Klebsiella spp. as a causative bacterial agents of enteritis in calves, Klebsiella spp. was isolated from diarrhoeic calves with a percentage of $2.3 \%$. This result agrees with that obtained by Ashraf (1996) and Hussain and Saikia (2000). They isolated Klebsiella spp. from diarrhoeic calves with an incidence of $3.8 \%, 2 \%, 1.8 \%$ and $3.2 \%$, respectively. On the other hand, our result differs from that obtained by Mona (1995) and Marcio et al. (2000). They recovered Klebsiella spp. from calves with diarrhoea in a percentage of $13.3 \%$ and $35.4 \%$, respectively.

As E. coli normal inhabitant in the intestinal tract of all worm blooded animals so its isolation from faeces of calves either diarrhoeic or apparently healthy have no significance unless we determine if it was pathogenic or non pathogenic. For this purpose Congo red binding activity of $E$. coli isolates was determined in this work. The result showed fundamental difference between the percentage of Congo red (CR) positive E. coli (Pathogenic) which recovered from diarrhoeic calves (83.7\%) and apparently healthy calves (31\%), while the Congo red negative E. coli (non pathogenic) was higher in apparently healthy calves $(69 \%)$ than from diarrhoeic $(16.3 \%)$. These results coincide with that obtained by Hoda (2006). They found that $87.3 \%$ (from diseased camels) and $80 \%$ (from diarrhoeic calves), respectively were CR positive E. coli. Also El-Bialy and Abd El-Aty (2002) demonstrated that all $E$. coli strains isolated from diarrhoeic foals and kids gave positive CR. Also, our results coincide with the results obtained by Mona (1995b). Accordingly, we can conclude that CR medium can be used as a rough method for in vitro differentiation between pathogenic and non pathogenic E. coli.

The pattern of antibiotic susceptibility of the most prevalent intestinal pathogens was done in vitro and the obtained data revealed 
that ciprofloxacin is the most effective antibiotics for $E$. coli with an activity percentage of $96.23 \%$ followed by enrofloxacin, ofloxacin and chloramphenicol with activity percentage of $88.68 \%, 85 \%$ and $77 \%$, respectively. The obtained results agree with that reported by Khaled (2004) who recorded higher sensitivity of E. coli to enrofloxacin and ciprofloxacin. On the other hand, these E. coli strains were resistant to clindamycin, oxytetracycline, colistin sulphate, amoxycillin and erythromycine $(15.1 \%, 17 \%, 30 \%, 35.84 \%$ and $39.62 \%$, respectively). These results agree with Khaled (2004) who reported that E. coli isolates were resistant to tetracycline and ampicillin. This may be possibly due to frequent use of these antibiotics where these farms commonly use a wide variety of antibiotics in the feed, water or as injectable drugs so the bacterial strains develop resistance to these antibiotics. Moreover, Abd El-Fattah (1990) reported that the sensitivity pattern of E. coli isolates from newly born calves against antibiotics was as follow: ampicillin (100\%), colistin $(89.1 \%)$, oxytetracycline $(59.3 \%)$ and neomycine $(87.2 \%)$.

Regarding to Salmonellae, three Salmonella serotypes were tested and found to be completely sensitive to chloramphenicol, cephalexine, cefotaxime, ampicillin (except $S$. ferruch), amoxycillin (except $S$. ferruch) and enrofloxacin (except $S$. cerro) but they were completely resistant to oxytetracycline, clindamycin and erythromycin.

Concerning $S$. kentucky, it was highly sensitive to chloramphenicol, cefotaxime, amoxycillin and ampicillin, while it was completely resistant to enrofloxacin, ertythromycin, oxytetracycline and clindamycin.

Regarding to $S$. ferruch, it was highly sensitive to ciprofloxacin, cefotaxime and enrofloaxacin, while it was completely resistant to erythromycine, oxytetracycline and clindamycine.

Concerning to $S$. cerro, it was highly sensitive to chloramphenicol, cefotaxime, and amoxycilinin while it was resistant to enrofloxacin, erythromycine, oxytetracycline and clindamycine. These results agree with that obtained by Dargatz et al. (2000) who reported that most of Salmonella isolated were resistant to tetracycline, ampicillin, chloramphenicol and streptomycine. So, the multidrug resistance phenomena are clear for salmonellae.

Regarding to possible involvement of fungal agents in calf diarrhoea in this study, the obtained finding revealed hat 12 isolates of yeasts were recovered and identified with an incidence of $7.2 \%$. 
Candida glabrata was the most prevalent fungal spp. isolated from routine samples $(58.3 \%)$. This result was near to that obtained by Elad et al. (1998) who recorded that $C$. glabrata was the only fungus shed by the calves. Higher incidence of $C$. glabrata was observed among diarrheic calves than healthy $(66.6 \%$ and $33.3 \%$, respectively) that suggests their role as one of the causes of diarrhoea although some yeast spp. may be considered as commonsals of digestive tract of calves (Elad et al., 1998).

C. guillermondi were isolated from diarrhoeic calves as well as healthy calves with an incidence of $22.2 \%$ and $66.6 \%$, respectively. Total Candida isolates were the most common isolates of yeasts recovered from cases of calf diarrhoea, this result is in agreement with Sebryokov et al. (1984).

However, it is important to study the role of these yeasts in the aetiology of diarrhoea. The more isolation doesn't indicate this role. However, the above cited authors agree in incriminating these yeasts as potential pathogens and as being capable of causing diarrhoea particularly after prolonged antibiotic therapy.

\section{REFERENCES}

Abd El-Fattah, M.A. (1990): The role of some antibiotics in treatment of bacterial diarrhoea in calves. M.V.Sc. Thesis, Fac. Vet. Med., Suez Canal. Univ.

Abd El-Galil, Y.; El-Kabbany, A. and Kiroloss, F. (1983): Studies on diarrhoea in buffalo calves: Bacterial causes and their sensitivity to a new synthetic bactericid imequyl in comparison with some antibiotics in vitro. Proceeding of VII ${ }^{\text {th }}$ International Symp. of World Association of Vet. Microbiologists, Immunologists and Specialists in Infectious Diseases, Barcelona, Spain.

Abou Zid, A.A. (1976): Studies on the ecology of calf salmonelosis in Egypt. M.V.Sc. Thesis, Fac. Vet. Med., Cairo Univ.

Abou-Zid, A.A. (1979): Studies on buffalo calves salmonellosis. Ph.D., Thesis, Fac. Vet. Med., Cairo Univ.

Al-Khayyat, A.; Abd-Allah, T.S.; Zafer, S.A.W. and Habasha, F.G. (1977): Severe outbreaks of calf scours in Baghdad province. Egypt. Vet. Med. J., 25, 221.

Ashraf, M.A. (1996): Studies on bacterial associated neonatal calf diarrhoea. M.V.Sc. Thesis, Fac. Vet. Med., Tanta Univ.

Bazeley, K. (2003): Investgation of diarrhoea in neonatal calves. Ind. practice, 25: 152-159. 
Berkhoff, H.A. and Vinal, A.C. (1986): Congo red medium to distinguish between invasive and non invasive Escherichia coli pathogenic for poultry. Av. Dis., 30(1), 117-121.

Corsalini, T. (1969): Enterobacteriaceae in the faeces of imported calves. Vet. Ital., 20: 686-698.

Cruickshank, R.; Duguid, J.P.; Marmion, B.P. and Swain, R.H.A. (1975): Medical Microbiology $12^{\text {th }}$ ed. volume II Churchill, livingstone Edinburgh, London and New York.

Dargatz, D.A.; Fedorka-cray, P.J.; Ladely, S.R. and Ferris, K.E. (2000): Survey of Salmonella serotypes shed in faeces of beef cows and their antimicrobial susceptibility patterns. J. food prot. 63 (12): 1648-53.

Elad, D.; Brenner, J.; Markovics, A.; Yakobson, B.; Shlomovitz, S and Basan, J. (1998): Yeasts in the gastrointestinal tracts of preweaned calves and possible involvement of Candida glabrata in neonatal calf diarrhoea. Mycopathologia, 141(1): 7-14.

El-Bialy, A.I. and Abd El-Aty, E. (2002): Virulence factors associated with different strains of $E$. coli isolated from diarrhoeic kids. SCVMJ, V, (1): 385-401.

Ewing, W.H. (1986): Edward's \& Ewings identification of enterobacteriaceae. $4^{\text {th }}$ Ed., Elsevier Science., New York.

Farid, A.; Ibrahim, M. and Refai, M. (1976): Studies on colibacillosis in Egypt. Zbl. Vet. Med. B. 23, 44.

Finegold, S.M. and Baron, E.J. (1986): Diagnostic microbiology, $7^{\text {th }}$ Ed. C.V. Mosby Company St. Louis, Toronto.

Hoda, M.M. (2006): Correlation between antigenic structures of E. coli and its virulence. Ph.D. Thesis, Fac. Vet. Med., Cairo Univ.

Hussain, I. and Saikia, G.K. (2000): Isolation and characterization of bacteria from diarrhoeic bovine calves. Indian J. Comp. Microbiol. Immunol. Infect. Dis., 21(2): 125-127.

Kauffmann, F. (1973): Serological diagnosis of Salmonella species. Kauffman- White Scheme, Copenhagen, Denmark.

Khaled, M.K. (2004): Studies on the role of Escherichia coli as a cause of cattle mastitis and its relationship to neonatal calf diarrhea. Ph.D. Thesis, Fac.Vet.Med.,Tanta Univ.

Koneman, E.W.; Allen, S.D.; Dando, M.W.; Schreckenberger, P.C. and Winn, M.C. (1997): Colour atlas of Diagnostic Microbiology. Fifth Edition, Lippincott, Philadelphia, New York. 
Koneman, E.W.; Allen, S.D.; Janda, W.M.; Schreckenberger, P.C. and Winn, W.C. (1995): Introduction to Diagnostic Microbiology. J. B. Lippincott Company Philadelphia, USA.

Krieg, N.R. and Holt, J.G. (1984): Bergey's Manual of systematic Bacteriology. Vol.1.William and Wilkins Company. Baltimore, London.

Labib, S.R.M. (1998): Salmonella outer membrane protein immunogenic properties in mice. Ph.D. Thesis, Fac. Vet. Med., Cairo Univ.

Marcio, G.R.; Langoni, H.; Jerez, J.A.; Leite, D.; Ferreira, F. and Gennari, S.M. (2000): Identification of entropathogens from buffalo calves with and without diarrhoea in the Ribeira Valley, State of Sao Paulo, Brazil. Braz. J. Vet. Res. Anim. Sci., 37(2).

Mona, A.A. (1995a): Studies on the bacterial causes of enteritis in buffalo calves in Ismailia Governorate. M.V.Sc. Thesis, Fac. Vet. Med., Zagazig Univ.

Mona, E.Z. (1995b): Characterization of E. coli isolated from broilers. M.VSc. Thesis, Fac. Vet. Med., Alex. Univ.

Navade, R.B.; Bhalerao, D.P.; Jagdish, S.; Samad, A. and Keskar, D.V. (2000): Neonatal calf diarrhoea: Serotyping of E. coli isolates. Indian Vet., J. 77(9): 815-816.

Oliveir, A.A.; Pedreira, P.A. and Almeida, M.F. (1989): Diseases of calves: 1- Bacterial diarrhoea in sergipe state, Brazil. Arquivo Brasileiro de Medicna Veterinaria Enzootecina. 41(3): 213.

Quinn, P.J.; Carter, M.E.; Markey, B.K.; Donnelly, W.J.C. and Leonard, F.C. (2002): Veterinary Microbiology and microbial diseases, Great Britain by MPG, Book. ltd, Bodmin, Cornwall, UK.

Radostitis, O.M.; Blood, D.C. and Gay, C.C. (1994): A text book of the diseases of the cattle; Sheep, Pigs, Goat and horses, Veterinary Medicine. $8^{\text {th }}$ Ed. Baillieve. Tindall Oxford, pp. 1016-1026.

Refai, M. (Ed.) (1987): Isolation and identification of fungi. Department of Microbiology, Faculty of Veterinary Medicine, Cairo University.

Sebryakov, E.V.; Parakin, V.K. and Voronyanskii, V.P. (1984): Candida mycosis in cattle and swine. Veterinariya, Moscow, USSR No. 3, 43-46.

Sirvastava, N.C. and Arya, S.C. (1979): E. coli serotypes in calves Ind. Vet. J., 56(11): 901-903.

Tanios, A.I.; Zaki, E.R.; El-Shrnoby, R.; Mona, A.; El-Shabrawy and Selem, R.S. (2000): Role of enteric bacteria in the aetiology of 
neonatal buffalo calves diarrhoea. Vet. Med. J. (Giza), 48(1): 65-72.

Tzipori, S. (1981): The etiology and diagnosis of calf diarrhoea. Vet. Rec. 108: 510-514.

Verma, K.C. and Aldakha, S.C. (1970): E. coli isolation from calves with diarrhoea. Ind. J. Anim. Hlth., 9: 107-108.

Verrtanyan, G.G.; Mezhlumyan, A.A. and Mnatsakanov, S.T. (1990): Pathogenicity of Enterobacteriaceae isolated from diarrhoeic calves. Biologiches Kii Zhurnal Armenii, 34(5): 401-404.

Wani, S.A.; Bhat, M.A.; Samanta, I.; Nishikawa, Y. and Buchh, A.S. (2003): Isolation and characterization of shigatoxin producing Escherichia coli and Enteropathogenic Escherichia coli from calves and lambs with diarrhoea in India. Lett. Appl. Microbiol., 37(2): 121-126.

Wells, S.J.; Fedorka-Cray, P.J.; Dargatz, D.A.; Ferris, K. and Green, A. (2001): Fecal shedding of Salmonella spp. by dairy cows on farm and at cull cow markets. Journal of Food Protection, 69, 1 (9): 3-11.

Woode, G.N. and Bridger, J.C. (1975): Viral enteritis of calves. Vet. Rec. 96, 58.

Zrelli, M.; Messadi, L.; Benmiled, L.; Jemli, M.H. and Haddad, N. (1990): Infective agents associated with calf neonatal diarrhoea in Tunisia. Revue de Medicine Veterinaire, 141(11), 861-872. 